\title{
Revitalisasi Konstitusional Penentuan Kandidat Presiden Melalui Pemilihan Demokratis di Internal Partai
}

\author{
Arlis* \\ Fakultas Syari'ah IAIN Imam Bonjol Padang \\ Jalan Anduring, Kuranji, Kota Padang, Sumatera Barat 25171, Indonesia
}

\begin{abstract}
Abstrak
Tujuan penelitian ini menjelaskan revitalisasi konstitusional dalam penentuan kandidat presiden melalui pemilihan demokratis di internal partai. Metode penelitian ini hukum normatif atau penelitian hukum doktrinal dengan pendekatan inventarisasi hukum. Hasil penelitian dapat dijelaskan bahwa secara konstitusional ditentukan bahwa negara berdasar atas Ketuhanan Yang Maha Esa. Oleh sebab itu, dalam konteks intensitas pemilihan demokratis dilaksanakan dengan prinsip Ketuhanan Yang Maha Esa. Hal yang demikian hendaknya di internal partai bahwa kandidat presiden dilaksanakan melalui pemilihan demokratis. Pemahaman dan aplikasi prinsip Ketuhanan Yang Maha Esa mesti dilaksanakan dengan benar, dengan maksud bahwa prinsip itu harus dipahami dan diaplikasikan berdasarkan ketentuan Tuhan Yang Maha Esa. Kondisi terakhir inilah yang menjadi persoalan diberbagai level kehidupan berbangsa dan bernegara, tidak terkecuali partai politik. Kesimpulan penelitian ini bahwa konsepsi revitalisasi konstitusional sebagai proses, cara, perbuatan menghidupkan atau menggiatkan kembali sesuai dengan konstitusi Indonesia dengan landasan filosofis Pancasila berbasiskan kepada Ketuhanan Yang Maha Esa demi wujudnya kebahagiaan bagi rakyat Indonesia. Revitalisasi konstitusional dalam penentuan kandidat presiden berkaitan dengan syarat kandidat presiden dan pemilihan demokratis. Syarat utama kandidat presiden adalah bertaqwa kepada Tuhan Yang Maha Esa, sedangkan pelaksanaan pemilihan demokratis mesti dengan prinsip amanah dan prosedur yang memberi ruang partisipasi seluruh rakyat dilandasi dengan prinsip Ketuhananan Yang Maha Esa. Penentuan kandidat presiden melalui pemilihan demokratis di internal partai dapat dilaksanakan dengan konvensi sehingga memberi ruang bagi kandidat terbaik yang dipilih oleh para pemilih terbaik untuk menjadi kandidat presiden.
\end{abstract}

\section{Kata Kunci: Revitalisasi Konstitusional, Kandidat Presiden, Pemilihan Demokratis, Internal Partai}

\begin{abstract}
The purpose of this study explains the constitutional revitalization in determining presidential candidates through democratic elections within the party's internal. This research method is normative law or doctrinal law research with law inventory approach. The results of the study can be explained that the constitutionally determined that the state based on Belief in the Almighty. Therefore, in the context of the intensity of democratic elections implemented with the principle of Belief in the One Supreme. Such a thing should be in
\end{abstract}

${ }^{*}$ Penulis Korespondensi

E-mail: arlis.antiko@gmail.com 
the internal party that the presidential candidate is implemented through democratic elections. Understanding and application of the principle of Belief in the One Supreme God must be carried out properly, with the intention that the principle must be understood and applied under the provisions of God Almighty. This last condition is a problem in various levels of national and state life, political parties are no exception. The conclusion of this research is that the conception of constitutional revitalization as a process, way, act of reviving or re-enacting in accordance with Indonesian constitution with philosophical basis of Pancasila based on Belief in God Almighty for the happiness of the people of Indonesia. Constitutional revitalization in the determination of presidential candidates relates to the terms of presidential candidate and democratic election. The main requirement of the presidential candidate is piety to God Almighty, while the implementation of democratic elections must be with the principle of trust and procedure that gives space for the participation of all people based on the principle of Godhead of the Almighty. Determination of presidential candidates through democratic elections on the party's internal can be implemented by convention to make room for the best candidates elected by the best voters to become presidential candidates.

\section{Keywords: Constitutional Revitalization, Presidential Candidate, Democratic Election, Internal Party}

\section{Pendahuluan}

Presiden di Indonesia merupakan pemegang kekuasaan pemerintahan. Selain sebagai kepala pemerintahan (head of government) presiden juga merupakan kepala negara (head of state). ${ }^{1}$ Konstitusi memberikan hak yang luas kepada presiden, selain menjalankan kekuasaan pemerintahan, tetapi dalam batas tertentu memiliki hak legislasi dan hak yudisial. $^{2}$

Sistem pemilihan umum presiden dan wakil presiden di Indonesia telah diatur dalam Undang-Undang Dasar Negara Kesatuan Republik Indonesia Tahun 1945 (selanjutnya
UUD NKRI Tahun 1945). ${ }^{3}$ Pasal 6A Ayat (2) UUD NKRI Tahun 1945 menyebutkan bahwa "pasangan calon presiden dan wakil presiden diusulkan oleh partai politik atau gabungan partai politik peserta pemilihan umum sebelum pelaksanaan pemilihan umum". Berdasarkan ketentuan pasal ini, diketahui bahwa partai politik memiliki peran yang menentukan dalam sebuah sistem demokrasi modern dan juga merupakan pilar utama dalam pranata sistem politik. ${ }^{4}$ Berarti pula kandidat presiden dan wakil presiden hanya diusung dari partai atau gabungan partai politik.

${ }^{1}$ Moh. Mahfud MD, Politik Hukum Proses Seleksi Pimpinan Lembaga Negara, Makalah disampaikan sebagai keynote speech pada konferensi Nasional Hukum Tata Negara ke-2, tanggal 11-12 September 2015 di Universitas Andalas, Padang, hlm. 5. Lihat juga Hendarmin Ranadireksa, Visi Bernegara Arsitektur Konstitusi Demokratik, (Bandung: Fokusmedia, 2009), hlm. 197.

${ }^{2}$ Todung Mulya Lubis, Problematika Seleksi Pejabat Negara: Presidensialisme yang tergerus? Makalah disampaikan sebagai keynote speech pada konferensi Nasional hukum tata Negara ke-2, tanggal 11-12 September 2015 di Universitas Andalas, Padang, hlm. 2.

${ }^{3}$ Kemitraan bagi Pembaharuan, Naskah Akademik dan RUU Kitab Hukum Pemilu, hlm. 32.

${ }^{4}$ Thomas Meyer, Peran Partai Politik dalam Sebuah Sistem Demokrasi: Sembilan Tesis, (Jakarta: Friedrich-Ebert-Stiftung (FES) Kantor Perwakilan Indonesia, 2012), hIm. 30. 
Penentuan kandidat merupakan inti dari tatanan demokrasi (in the core of any democratic order) dan merupakan kegiatan mendasar dalam proses politik (a fundamental activity in the political process). ${ }^{5}$ Pemilihan presiden merupakan salah satu proses politik tersebut. Penentuan kandidat presiden senantiasa menjadi isu yang menarik disebabkan jumlah jabatan presiden hanya satu dalam suatu negara. ${ }^{6}$

UUD NKRI Tahun 1945 tidak menentukan mekanisme penentuan calon di tingkat partai politik. Untuk pemilihan presiden dan wakil presiden sejak tahun 2004 telah diadakan pemilihan langsung oleh rakyat. ${ }^{7}$ Pemilihan umum presiden dan wakil presiden secara langsung mempertegas sistem pemerintahan presidensil. $^{8}$

Pemilihan presiden dan wakil presiden seharusnya tetap mengakomodir usulan bukan dari partai politik atau gabungan partai politik (independen). Meskipun ada pendapat pencalonan presiden independen memiliki lebih banyak kekurangan daripada keunggulan. Karena hanya diusung dari partai atau gabungan partai politik maka sistem pemilihan umum presiden dan wakil presidendi Indonesia belum mengakomodasi prinsip demokrasi secara penuh. ${ }^{9}$

Ketentuan UUD NKRI Tahun 1945 terkait pemilihan presiden secara teknis dijabarkan lebih lanjut dengan undang-undang, sedangkan dalam partai politik terdapat mekanisme dalam anggaran dasar dan anggaran rumah tangga (AD/ART). ${ }^{10}$ Dalam kajian ini, penulis akan meninjau sistem pemilihan umum presiden dan wakil presiden dalam undang-undang terdahulu, yaitu Undang-Undang Nomor 42 Tahun 2008 tentang Pemilu Presiden dan Wakil Presiden. ${ }^{11}$

Setiap partai politik yang dilengkapi dengan AD/ART, kelihatannya tidak menjamin terwujudnya penentuan kandidat presiden

${ }^{5}$ Miguel Pérez-Moneo, Regulating nominations in political parties: Candidates, primaries and Law, https : // www .jus . ui. No /english/ research /news-and-events / events / conferences $/ 2014 / \mathrm{wccl} \mathrm{cmdc} / \mathrm{wccl} /$ papers/ ws13/ w13-perez-moneo. pdf, diakses pada hari Rabu, 27 April 2016 jam 10. 00 WIB.

${ }^{6}$ Ramlan Surbakti dkk, Naskah Akademik dan Draft RUU Kitab Hukum Pemilu: Usulan Masyarakat Sipil, (Jakarta: Kemitraan bagi Pembaruan Tata Pemerintahan di Indonesia, 2015), hlm. 131.

${ }^{7}$ Sumono, Pemilihan Presiden dan Wakil Presiden Berdasarkan Sistem Presiden, Makalah dalam Seminar Nasional dan Call For Papers Uniba 2014, hlm. 63.

${ }^{8} \mathrm{Abu}$ Tamrin, Urgensi Pemilu Presiden dan Wakil Presiden Secara Langsung di Era Reformasi, Jurnal Cita Hukum, Volume I, Nomor 2, Desember 2013, hlm. 194.

${ }^{9}$ Muh. Ikhsan Baso, Sistem Pemilihan Umum Presiden dan Wakil Presiden Indonesia Dengan Pencalonan Secara Independen (Perseorangan), Jurnal IImu Hukum Legal Opinion, Edisi 5, Volume 1, Tahun 2013, hlm. 8.

${ }^{10}$ Partai GOLKAR bersifat mandiri, terbuka, demokratis, moderat, solid, mengakar, responsif, majemuk, egaliter, serta berorientasi pada karya dan kekaryaan (AD ART Partai Golkar). Watak Partai GERINDRA adalah demokratis, merdeka, pantang menyerah, berpendirian teguh, percaya pada kekuatan sendiri dan kekuatan rakyat, terbuka dan taat hukum serta senantiasa memiliki watak sebagai pejuang yang berjuang untuk kepentingan rakyat (AD ART Partai Gerindra). Usaha sebagaimana dimaksud pada Ayat (1) dilaksanakan secara demokratis dan konstitusional (AD ART partai Persatuan Pembangunan). Tujuan umum didirikannya Partai ini adalah terwujudnya cita-cita nasional bangsa Indonesia sebagaimana dimaksud dalam Pembukaan UUD Tahun 1945 dan berkembangnya kehidupan demokrasi dengan menghormati kedaulatan rakyat dalam Negara Kesatuan Republik Indonesia berdasarkan prinsip-prinsip ajaran Islam (AD ART Partai Bulan Bintang). Watak Partai adalah gotong royong, demokratis, merdeka, pantang menyerah dan terbuka (AD ART PDI Perjuangan). Partai bersifat kebangsaan, demokratis dan terbuka (AD ART Partai PKB).

${ }^{11}$ Kemitraan bagi Pembaharuan, Loc. Cit. 
melalui pemilihan demokratis di internal partai. Sementara,rakyat terpaksa harus memilih calon presiden yang disodorkan partai politik. ${ }^{12}$ Menurut Slamet belum tentu proses seleksi calon presiden dan wakil presidendi internal partai politik memenuhi mekanisme yang demokratis sebagaimana yang dikehendaki masyarakat. Slamet mengingatkan bahwa partai politik cenderung bersifat oligarchy atau mempertahankan kekuasaannya pada sekelompok orang/golongan saja. Jadi, bukan tidak mungkin dalam proses seleksi calon presiden dan wakil presiden tersebut terdapat kepentingan kelompok yang dikedepankan. ${ }^{13}$

Pengusungan atau dukungan partai politik terhadap calon presiden dan wakil presiden yang sangat elitis dan berkonflik. Hal ini dapat dilihat dari beberapa kejadian internal politik yang rapuh karena kader tidak dilibatkan dalam mekanisme pengusungan calon presiden. Contohnya pada tingkat nasional Partai Persatuan Pembangunan (PPP) ketika Surya Dharma Ali selaku Ketua Umum PPP sepihak memberikan dukungan kepada Prabowo Subianto dan Hatta Rajasa, bahkan sebelum pemilihan legislatif terjadi. ${ }^{14}$ Begitu juga dengan Partai Golongan Karya (Partai Golkar), para kader seniornya menganggap Abu Rizal Bakrie terlalu egois dan terburu-buru dalam menambatkan dukungan kepada Prabowo. Perpecahan di tubuh Partai Golkar dapat terlihat dari pembangkangan beberapa kadernya mendukung Joko Widodo dan Jusuf Kalla, seperti Luhut Pandjaitan, Nudirman Munir, dan lain-lain. ${ }^{15}$ Bahkan setelah pemilihan presiden keretakan di Partai Golkar semakin kentara dengan adanya Musyawarah Nasional (Munas) tandingan. ${ }^{16}$ Partai Kebangkitan Bangsa (PKB) yang pada awalnya diberitakan akan mengusung Rhoma Irama sebagai calon presiden, namun setelah perolehan suara PKB naik pada pemilu legislatif tahun 2014maka pencalonan Rhoma Irama justru batal.

Berdasarkan kondisi tersebut maka mekanisme penentuan calon presiden dan wakil presiden yang dilakukan oleh partai politik selama ini berlangsung secara tidak demokratis. ${ }^{17}$ Sehingga diperlukan kajian untuk menguji pernyataan bahwa Indonesia menjadi contoh dari sukses negara demokrasi. ${ }^{18}$

${ }^{12 Z a e}$, Perlu Seleksi Internal Partai yang Demokratis Soal Capres, http : // www . hukumonline.com/ berita /baca/ hol 7729/ perlu-seleksi-internal-partai-yang-demokratis-soal-capres, diakses pada hari Senin, 27 Juni 2016 jam 23.00 WIB.

${ }^{13}$ lbid.

${ }^{14}$ Ican Ihsannuddin, Suryadharma Tak Cabut Dukungannya kepada Prabowo, http : // nasional .kompas . com / read/2014 / 04 / 21 / 2116433 /Suryadharma. Tak. Cabut. Dukungannya. Kepada. Prabowo, diakses pada hari Senin, 27 Juni 2016 jam 23.00 WIB.

${ }^{15}$ Fabian. 2014. Tokoh Senior Golkar Dukung Jokowi, Laman Kompas online, diakses dari http : // nasional . kompas . com / read / 2014 / 06 / 16 / 1842124 / tokoh . senior . golkar . dukung. Jokowijk . karena .keduanya. jujur dan. tulus, tanggal 04/01/2015 jam 20.00 WIB. Fitri Sartina Dewi, Isu Golkar Pecah Politisi Senior Tolak Pemecatan Kader Golkar Pendukung Jokowi-JK,http://www.solopos.com/ 2014/ 05/ 22/ isugolkar-pecah-politisi-senior-tolak-pemecatan-kader-golkar-pendukung-jokowi-jk-509253, diakses pada hari Senin, 27 Juni 2016 jam 23.00 WIB.

${ }^{16}$ Andi Muttya Keteng, Muncul Munas Tandingan, Golkar Tetap Gelar Munas 30 November,http:// news.liputan6.com/read/2139505/muncul-munas-tandingan-golkar-tetap-gelar-munas-30-november, diakses pada hari Senin, 27 Juni 2016 jam 23.00 WIB.

${ }^{17}$ Ibid.

${ }^{18}$ Farahdiba Rahma Bachtiar, Pemilu Indonesia: Kiblat Negara Demokrasi dari Berbagai Refresentasi, Jurnal Profetik, Volume 3, Nomor 1, Tahun 2014, hlm. 25. 
Realitas yang ada sangat penting untuk melakukan revitalisasi konstitusional dalam penentuan kandidat calon presiden dan wakil presiden melalui pemilihan demokratis di internal partai. Beberapa pertimbangan secara kronologis revitalisasi konstitusional menjadi sangat penting karena:

1. Negara Indonesia diselenggarakan secara konstitusional.

2. Presiden adalah pemegang kekuasaan pemerintahan negara.

3. Calon presiden dan wakil presiden diusulkan oleh partai politik dan gabungan partai politik.

4. Pemilihan presiden dan wakil presiden dilaksanakan melalui pemilihan umum (pemilu).

5. Pemilu dilaksanakan secara demokratis.

Memperhatikan pertimbangan di atas dapat diketahui bahwa pemilihan presiden dan wakil presiden yang demokratis harus dimulai di internal partai politik. Oleh sebab itu, fokus utama penelitian ini terkait revitalisasi konstitusional dengan mengedepankan tinjauan filosofis dan normatif terhadap teks UUD NKRI Tahun 1945 dilengkapi dengan aturan undangundang. Untuk kajian di internal partai dilakukan tinjauan dengan menganalisisAD/ART partai politik. Alasan dan dasar pemikiran pembahasan revitalisasi konstitusi tidak terlepas daripentingnya posisi konstitusi (UUD NKRI Tahun 1945) dalam suatu negara. UUD NKRI Tahun 1945 ditempatkan pada kedudukan yang tinggi (supreme). Ada semacam jaminan bahwa konstitusi itu akan diperhatikan dan ditaati. ${ }^{19}$

Penelitian tentang revitalisasi konstitusional dalam penentuan kandidat presiden melalui pemilihan demokratis di internal partai belum pernah disentuh oleh penulis lain. Beberapa terdahulu diantaranyaSri Handayani Retna Wardani hanya meneliti tentang tolok ukur demokrasi Pancasila dalam membentuk Undang-Undang Pemilu Legislatif. Hasil penelitiannya menjelaskan pembentukan undang-undang bidang politik tidak menggunakan model dan tidak sesuai dengan konsep negarahukum sebagaimana diamanatkan dalam konstitusi (UUD NRI Tahun1945) dan tidak sesuai denganideologi Pancasila sebagai landasan filosofisnya. ${ }^{20}$

Wimmy Halim pernah meneliti tentang demokrasi deliberatif indonesia: konsep partisipasi masyarakat dalam membentuk demokrasi dan hukum yang responsif. Dalam penelitiannya dijelaskan kekuatan konstituen dapat membentuk hukum dalam sistem demokrasi deliberatif dan direct popular checks atau pemeriksaan langsung oleh masyarakat. Artinya,masyarakat ditempatkan sebagai sebuah pilar yang dapat mengawasi jalannya pemerintahan. Pada hakikatnya,sistem ini merupakan sarana-sarana ultra-demokrasi yang merupakan perluasan proses legislatif di luar majelis yang dibentuk oleh masyarakat. Hal ini menjadi penting dalam rangka peningkatan kualitas demokrasi Indonesia. ${ }^{21}$

Lambang Trijono meneliti tentang reaktualisasi politik demokrasi: politik agensi

\footnotetext{
${ }^{19}$ Ni'matul Huda, UUD 1945 dan Gagasan Amandemen Ulang, (Jakarta: Rajawali Pers, 2008), hlm. 27.

${ }^{20}$ Sri Handayani Retna Wardani, Tolok Ukur Demokrasi Pancasila Dalam Membentuk Undang-Undang Pemilu Legislatif, Jurnal Kajian Hukum, Volume 1, Nomor 1, Mei 2016, hlm. 92.

${ }^{21}$ Wimmy Halim, Demokrasi Deliberatif Indonesia: Konsep Partisipasi Masyarakat Dalam Membentuk Demokrasi dan Hukum yang Responsif, Jurnal Masyarakat Indonesia, Volume 42, Nomor 1, Juni 2016, hlm. 19.
} 
dan revitalisasi kelembagaan demokrasi. Dalam penelitiannya menggarisbawahi wacana pembentukan subyek politik baru melalui pengembangan model politik agonistik yang diasumsikan dapat lebih merepresentasikan kepentingan publik dan mampu mengaktivasi lembaga-lembaga politik untuk kembali menjalankan fungsinya. ${ }^{22}$

Abdul Latif pernah menulis tentang pemilihan presiden (pilpres) dalam perspektif koalisi multipartai. Dalam tulisannya dijelaskan bahwa perlu persepsi yang sama tentang sistem pemerintahan. Sistem campuran harus jelas bagian-bagian yang menggunakan sistem parlementer dan bagian yang masih menggunakan sistem presidensil. Ketidakjelasan sistem campuran akan menimbulkan kekaburan tentang hak dan kewajiban Presiden. Kebenaran yang didasarkan suara terbanyak tidak selalu menggambarkan kualitas yang didukung oleh kebenaran teoritik. ${ }^{23}$

Bila ditelaah penelitian terdahulu tersebut jelas tidak ada kaitannya dengan revitalisasi konstitusional dalam penentuan kandidat presiden melalui pemilihan demokratis di internal partai. Adapun permasalahan yang dibahas dalam penelitian ini terkait dengan konsepsi revitalisasi konstitusional dalam penentuan kandidat presiden dan penentuan kandidat presiden melalui pemilihan demokratis di internal partai. Hasil yang diharapkan dari penelitian ini untuk menjelaskan revitalisasi konstitusional dalam penentuan kandidat presiden melalui pemilihan demokratis di internal partai. Selain itu, penelitian ini diharapkan dapat dijadikan pengembangan ilmu pengetahuan khususnya hukum tata negara.

\section{Metode Penelitian}

Penelitian ini adalah penelitian hukum normatif atau penelitian hukum doktrinal dengan pendekatan inventarisasi hukum, yaitu mengumpulkan norma-norma yang sudah diidentifikasi sebagai norma hukum. Sebagai penelitian hukum normatif maka sumber data yang dipergunakan berupa data sekunder, terdiri dari bahan hukum primer, sekunder dan tersier. Analisis data penelitian secara secara kualitatif, yakni membandingkan atau menerapkan peraturan perundang-undangan yang berlaku, pendapat para sarjana (doktrin) serta teori-teori hukum lainnya. Kesimpulan penelitian secara deduktif, yakni penarikan kesimpulan diawali dari yang bersifat umum kepada yang bersifat khusus.

\section{Pembahasan}

\section{Konsepsi Revitalisasi Konstitusional}

Revitalisasi konstitusional secara bahasa terdiri dari 2 kata, yaitu kata revitalisasi dan konstitusional. Pengertian kata revitalisasi disebut juga dengan istilah revitalization (Bahasa Inggris), ${ }^{24}$ tanshith (Bahasa Arab), revitalisering (Bahasa Belanda), revitalización (Bahasa Spanyol), Revitalisierung (Bahasa Jerman), pervulgent (Bahasa Latin). ${ }^{25}$

\footnotetext{
22Lambang Trijono, Reaktualisasi Politik Demokrasi: Politik Agensi dan Revitalisasi Kelembagaan Demokrasi, Jurnal IImu Sosial dan IImu Politik, Volume 15, Nomor 2, November 2011, hIm. 93.

${ }^{23}$ Abdul Latif, Pilpres Dalam Perspektif Koalisi Multiparta, Jurnal Konstitusi, Volume 6, Nomor 3, September 2009, hlm. 49.

${ }^{24} \mathrm{~J}$ John M. Echols dan Hassan Shadily, Kamus Indonesia Inggris, (Jakarta: PT Gramedia, 2002), hlm. 461.

${ }^{25}$ Terjemahan, revitalisasi, https://translate.google.com/?hl=id\#id/la/revitalisasi, diakses pada hari Senin, 27 Juni 2016 jam 23.00 WIB.
} 
Revitalisasi berarti the process of making something grow, develop, or become successful again. ${ }^{26}$ Pengertian ini dimaksudkan sebagai proses pembuatan sesuatu tumbuh, berkembang atau menjadi sukses lagi. Revitalisasi juga berarti proses, cara, perbuatan menghidupkan atau menggiatkan kembali. ${ }^{27}$ Menghidupkan bermakna menjadikan (membuat, menyebabkan) hidup, membangkitkan kembali. ${ }^{28}$ Menggiatkan dimaksudkan membuat menjadi giat (aktif, bergairah, dan bersemangat, mengaktifkan, mendorong (memberi atau membangkitkan semangat dan sebagainya) supaya menjadi lebih giat, menggalakkan, memperhebat). ${ }^{29}$

Kata Konstitusional disebut dengan istilah constitutional (Bahasa Inggris), ${ }^{30}$ dusturiy (Bahasa Arab), grondwettelijk (Bahasa Belanda), costituzionale (Bahasa Italia), constitucional (Bahasa Spanyol), constitutionalis (Bahasa Latin). ${ }^{31}$ Pengertian konstitusional secara sederhana (simple definition of constitusional) menurut kamus of or relating to the system of beliefs and laws that govern a country: of or relating to a constitution: allowed by a country's constitution. ${ }^{32}$ Konstitusional juga diartikan dengan makna, kesesuaian dengan, atau diatur oleh konstitusi suatu negara. ${ }^{33}$

Berdasarkan pengertian masing-masing kata revitalisasi dan konstitusional dapat dirumuskan makna revitalisasi konstitusional sebagai proses, cara, perbuatan menghidupkan atau menggiatkan kembali sesuai dengan konstitusi suatu negara (dalam konteks ini konstitusi Negara Kesatuan Republik Indonesia berupa UUD NKRI Tahun 1945).

Proses, cara, perbuatan menghidupkan atau menggiatkan kembali sesuai dengan konstitusi Negara Kesatuan Republik Indonesia karena negara Indonesia memiliki beban dan komitmen moral untuk secara aktif turun ke lapangan (affirmative action) mewujudkan kebahagiaan bagi rakyat Indonesia. Pembacaan terhadap konstitusi seperti itu memunculkan konstruksi, terdapat nilai dan komitmen moral penting yang ingin diwujudkan, yaitu menghadirkan dan membangun negara yang membahagiakan rakyatnya. Semua hal yang tercantum dalam Pancasila dan UUD NKRI Tahun 1945 menunjukkan arah moral tersebut. Dicantumkannya Sila Ketuhanan Yang Maha Esa, yang meta rasional memberikan warna unik dan watak khasserta sekaligus menjadi alasan penting untuk mengatakanbahwa negara Indonesia menginginkan agar rakyat hidup bahagia. Berangkat dari sila pertama berupa Ketuhanan Yang Maha Esa maka Negara Indonesia harus menjadi rahmat bagi rakyatnya. ${ }^{34}$ Oleh sebab itu, berdasarkan konsep revitalisasi konstitusional mestinya

\footnotetext{
${ }^{26} \mathrm{http}: / /$ dictionary.cambridge.org/dictionary/english/revitalization, pada hari Senin, 27 Juni 2016 jam $09.00 \mathrm{WIB}$. hlm. 954.

${ }^{27}$ Departemen Pendidikan Nasional, Kamus Besar Bahasa Indonesia, (Jakarta: Balai Pustaka, 2003),

${ }^{28} / \mathrm{bid}, \mathrm{hlm} .400$.

${ }^{29} \mathrm{lbid}$, hlm. 362.

${ }^{30} \mathrm{John}$ M. Echols dan Hassan Shadily, Kamus Indonesia... Op.Cit., hlm. 307.

${ }^{31} \mathrm{https}$ ://translate.google.com, diakses pada hari Senin, 27 Juni 2016 jam 23.00 WIB.

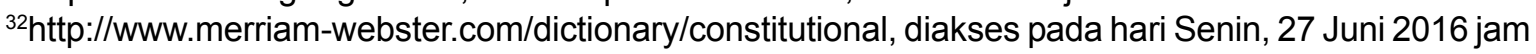
23.00 WIB.

${ }^{33}$ Departemen Pendidikan Nasional, Kamus Besar...Op.Cit., hlm. 590.

${ }^{34}$ Satjipto Rahardjo, Negara Hukum yang Membahagiakan Rakyatnya, (Yogyakarta: Genta Publishing, 2009), hlm. 93-94.
} 
penentuan kandidat presiden dan wakil presiden melalui pemilihan demokratis di internal partai mutlak dilandasi oleh prinsip Ketuhanan Yang Maha Esa.

\section{Revitalisasi Konstitusional Penentuan Kandidat Presiden dan Wakil Presiden}

1. Revitalisasi konstitusional tentang syarat calon presiden dan wakil presiden

Berdasarkan Pasal 6 Ayat (1) dan Pasal 6 A Ayat (2) UUD NKRI Tahun 1945, calon presiden dan calon wakil presiden harus memenuhi syarat sebagai berikut.

a. Warga negara Indonesia sejak kelahirannya dan tidak pernah menerima kewarganegaraan lain karena kehendaknya sendiri.

b. Tidak pernah mengkhianati negara.

c. Mampu secara rohani dan jasmani untuk melaksanakan tugas dan kewajiban sebagai presiden dan wakil presiden.

d. Dipilih dalam satu pasangan secara langsung oleh rakyat.

e. Diusulkan oleh partai politik atau gabungan partai politik peserta pemilihan umum sebelum pelaksanaan pemilihan umum.

Ketentuan UUD NKRI Tahun 1945 menyebutkan bahwa calon presiden dan calon wakil presiden harus mampu secara rohani dan jasmani untuk melaksanakan tugas dan kewajibannya. Persoalannya, siapa yang dikategorikan mampu tersebut dengan menggunakan prinsip revitalisasi konstitusional maka mutlak memaknai secara intensif ketentuan dalam UUD NKRI secara komprehensif, bukan sepotong-sepotong. Karena ketentuan UUD NKRITahun 1945 adalah penjabaran dari Pancasila yang dijiwai dengan prinsip Ketuhanan Yang Maha Esa. Oleh sebab itu, intensitas pemaknaan kata mampu mutlak dioptimalkan sesuai dengan ketentuan Tuhan Yang Maha Esa.

Dalam konteks ini, Tuhan Yang Maha Esa telah memberikan potensi kepada segenap Warga Negara Indonesia untuk menjadi pemimpin sesuai dengan amanah konstitusi. Walaupun demikian, dalam perkembangannya tidak setiap orang mampu mengembangkan potensi kepemimpinan, sehingga hanya orangorang tertentu saja yang menjadi kandidat presiden dan wakil presiden yang dicalonkan oleh partai politik atau gabungan partai politik.

Upaya merintis intensitas revitalisasi konstitusional penting artinya untuk memahami spirit yang mengemuka ketika dilakukan proses Amandemen UUD NKRI Tahun 1945. Usulanusulan yang muncul dalam Amandemen UUD NKRI Tahun 1945 sebagai berikut.

a. Syarat-syarat keadaan diri secara lengkap itu diatur dengan undangundang, agar bisa lebih teliti, lebih luwes, lengkap, utuh, dan terpadu. ${ }^{35}$

b. Berkaitan dengan mental, didefinisikan oleh kalangan medis berupa rangeyang luas. Menurut kalangan agamawan, bicara tentang mental tentang sesuatu yang tidak jelas batasannya sehingga tidak mungkin dijabarkan terlalu rinci dalam UUD NKRI Tahun 1945. Hal ini

${ }^{35}$ Bagian dari paparan Afandi dari F-TNI/Polri, alasan mengapa syarat keadaan diri diatur dengan undangundang. Mahkamah Konstitusi RI, Naskah Komprehensif Perubahan Undang-Undang Dasar Negara Republik Indonesia Tahun 1945 Buku IV Kekuasaan Pemerintahan Negara, Jilid I, (Jakarta: Sekretariat Jenderal dan Kepaniteraan MK, 2010), hlm. 178. 
diatur lebih lanjut dengan undangundang, karena di tingkat undangundang terdapat bagian penjelasan yang dapat uraikan lebih terperinci. Intinya bahwa memang seorang calon presiden dan calon wakil presiden itu harus ada persyaratan jelas. Tapi persyaratan yang seperti apa, itu harus dengan persepsi yang sama dan harus terperinci dijelaskan. Misalkan, pengertian cacat, fisik, psikis, dan lain sebagainya. ${ }^{36}$

c. Tentang persyaratan yang akan dipilih itu memang orang yang sempurna, sehat lahir batin, mental, dan fisiknya. Meskipun ada di antara kepala negara yang pernah tidak sempurna. Tetapi, dalam 250-an juta rakyat Indonesia apa tidak ada yang sempurna. Apalagi nantinya akan dipilih oleh rakyat secara langsung. Oleh karena itu, diharapkan agar syarat sehat mental dan fisik itu harus dicantumkan pada konstitusi. Nantinya, secara rinci bagaimana keterangan sehat fisik, mental dicantumkan pada undang-undang. ${ }^{37}$

d. Syarat pengajuan yang tidak debatable, karena itu menjadi persyaratan yang mendasar termasuk jasmani dan rohani. Jasmani dan rohani pun menjadi syarat untuk semua, calon pegawai negeri atau calon apapun biasanya diminta syarat dengan surat keterangan menjadi suatu hal yang umum. Tapi, kalau untuk mengatur supaya tidak diperdebatkan, terkait dengan klausul Ayat (2) itu sebenarnya sudah bisa menyelesaikan masalah. Undang-undang mengatur bagaimana sehat jasmani dan rohani calon, sehingga menjadi persyaratan mendasar. $^{38}$

Usulan-usulan yang mengilhami lahirnya ketentuan dalam UUD NKRI Tahun 1945 yang menentukan persyaratan untuk menjadi calon presiden dan wakil presiden sebagaimana diatur pada Pasal 6 Ayat (2) UUD NKRI Tahun 1945. Penyelenggaraan pemilihan umum yang demokratis,dibentuklah pengaturan berupa undang-undang maupun turunnyayang menjelaskan lebih rinci persyaratan maupun teknis pelaksanaan pemilu. Dalam hal pemilu presiden dan wakil presiden, terdahulu dibentuk dengan Undang-UndangNomor 23 Tahun 2003 yang kemudian diubah dengan Undang-Undang Republik Indonesia Nomor 42 Tahun 2008 tentang PemilihanUmum Presiden dan Wakil Presiden. ${ }^{39}$

Pasal 6 Undang-Undang Nomor 23 Tahun 2003 tentang Pemilihan Umum Presiden dan Wakil Presiden menentukan syarat bagi calon presiden dan calon wakil presiden sebagai berikut.

a. Bertaqwa kepada Tuhan Yang Maha Esa.

b. Warga negara Indonesia sejak kelahirannya dan tidak pernah menerima kewarganegaraan lain karena kehendaknya sendiri.

c. Tidak pernah mengkhianati negara.

${ }^{36} / \mathrm{bid}, \mathrm{hlm} .180$.

${ }^{37} \mathrm{Ibid}, \mathrm{hlm} .185$.

${ }^{38} \mathrm{Ibid}, \mathrm{hlm} .190$.

${ }^{39}$ Ahmad Farhan Subhi, Pengusulan Pasangan Calon Presiden dan Wakil Presiden Sebagai Peserta Pemilu Menurut Undang-Undang Pilpres, Jurnal Cita Hukum, Fakultas Syariah dan Hukum UIN Syarif Hidayatullah Jakarta, Volume II, Nomor 2, Tahun 2015, hlm. 341. 
d. Mampu secara rohani dan jasmani untuk melaksanakan tugas dan kewajiban sebagai presiden dan wakil presiden.

e. Bertempat tinggal dalam wilayah Negara Kesatuan Republik Indonesia.

f. Telah melaporkan kekayaannya kepada instansi yang berwenang memeriksa laporan kekayaan penyelenggara negara.

g. Tidak sedang memiliki tanggungan utang secara perseorangan dan/atau secara badan hukum yang menjadi tanggung jawabnya yang merugikan keuangan negara.

h. Tidak sedang dinyatakan pailit berdasarkan putusan pengadilan.

i. Tidak sedang dicabut hak pilinnya berdasarkan putusan pengadilan yang telah mempunyai kekuatan hukum tetap.

j. Tidak pernah melakukan perbuatan tercela.

k. Terdaftar sebagai pemilih.

I. Memiliki Nomor Pokok Wajib Pajak (NPWP) dan telah melaksanakan kewajiban pajak selama 5 (lima) tahun terakhir yang dibuktikan dengan Surat Pemberitahuan Tahunan Pajak Penghasilan Wajib Pajak Orang Pribadi.

m. Memiliki daftar riwayat hidup.

n. Belum pernah menjabat sebagai presiden dan wakil presiden selama dua kali masa jabatan dalam jabatan yang sama.

o. Setia kepada Pancasila sebagai dasar negara, UUD Tahun 1945, dan cita-cita Proklamasi 17 Agustus 1945. p. Tidak pernah dihukum penjara karena melakukan tindak pidana makar berdasarkan putusan pengadilan yang telah mempunyai kekuatan hukum tetap.

q. Berusia sekurang-kurangnya 35 (tiga puluh lima) tahun.

r. Berpendidikan serendah-rendahnya SLTA atau yang sederajat.

s. Bukan bekas anggota organisasi terlarang Partai Komunis Indonesia, termasuk organisasi massanya, atau bukan orang yang terlibat langsung dalam G 30 S/PKI.

t. Tidak pernah dijatuhi pidana penjara berdasarkan putusan pengadilan yang mempunyai kekuatan hukum tetap karena melakukan tindak pidana yang diancam dengan pidana penjara lima tahun atau lebih.

Konsep revitalisasi konstitusional berupa syarat bertaqwa kepada Tuhan Yang Maha Esa. Kesalehan seorang pemimpin negara diukur pada seberapa baik akhlaknya, seberapa kuat komitmen dan kemampuanuntuk mencapai tujuan kepemimpinan untuk menegakkan keadilan dan kemakmuran bagi segenap rakyat. ${ }^{40}$ Ketentuan Tuhan yang menyebut tentang syarat takwa sebagai berikut.

a. And believe in what I reveal, confirming the revelation which is with you, and be not the first to reject Faith therein, nor sell My Signs for a smallprice; and fear Me, and Me alone (Q.S. Baqara (2) : 41).

b. It is not righteousness that ye turn your faces towards east or west; butit is righteousness- to believe in Allah and 109.

${ }^{40}$ Masdar Farid Mas'udi, Syarah UUD 1945 Perspektif Islam, (Jakarta: PT Pustaka Alvabet, 2013), hlm. 
the last day, and the angels, andthe book, and the messengers; to spend of your substance, out of love for Him,for your kin, for orphans, for the needy, for the wayfarer, for those who ask, and for the ransom of slaves; to be steadfast in prayer, and practice regularcharity; to fulfil the contracts which ye have made; and to be firm and patient,in pain [or suffering] and adversity, and throughout all periods of panic. Suchare the people of truth, the Allah-fearing(Q.S. Baqara (2): 177).

c. The prohibited month for the prohibited month,- and so for all thingsprohibited,there is the law of equality. If then any one transgresses theprohibition against you, transgress ye likewise against him. But fear Allah, andknow that Allah is with those who restrain themselves(Q.S. Baqara (2): 194).

d. O ye who believe! Fear Allah, and give up what remains of your demand forusury, if ye are indeed believers (Q.S. Baqara (2): 278).

Bila ditinjau cita negara Hukum Indonesia yang berdasarkan Pancasila, ide kenegaraan tidak dapat dilepaskan dari nilai Ketuhanan Yang Maha Esa Sila Pertama dari Pancasila. Oleh karena itu, negara Indonesia menjunjung tinggi nilai-nilai ke-Maha Esaan dan ke-Maha Kuasaan Tuhan. Artinya, diakuinya prinsip supremasi hukum tidak mengabaikan keyakinan mengenai ke-Maha Kuasa-an Tuhan Yang Maha Esa yang diyakini sebagai Sila Pertama dari Pancasila. Pengakuan segenap bangsa Indonesia mengenai kekuasaan tertinggi yang terdapat dalam hukum tidak boleh bertentangan dengan keyakinan segenap warga bangsa mengenai prinsip dan nilai-nilai ke-Maha-Kuasa-an Tuhan Yang Maha Esa dan di pihak lain pengakuan akan prinsip supremasi hukum itu juga merupakan pengejawantahan atau ekspresi kesadaran rasional kenegaraan atas keyakinan pada Tuhan Yang Maha Esa yang menyebabkan setiap manusia Indonesia hanya memutlakkan Yang Esa dan menisbikan kehidupan antar sesama warga yang bersifat egaliter dan menjamin persamaan dan penghormatan atas kemajemukan dalam kehidupan bersama dalam wadah negara Pancasila. ${ }^{41}$

Menyertakan moral Ketuhanan sebagai dasar negara memberikan dimensi transcendental pada kehidupan politik serta mempertemukan hubungan simbiosis antara konsepsi daulat Tuhan dan daulat rakyat. Pancasila dalam kehidupan kebangsaan dan kenegaraan terangkat dari tingkat sekuler ke tingkat moral atau sakral. Rekonsiliasi antara tendensi kearah sekularisasi dan sakralisasi dengan wawasan Ketuhanan diharapkan dapat memperkuat etos kerja, karena kualitas kerja ditransendensikan dari batasan hasil kerja materialnya. Oleh karena itu, teologi kerja yang transendental memberi nilai tambah spiritual maka memperkuat motivasi di satu pihak dan di pihak lain memperbesar inspirasi dan aspirasi warga negara. Wawasan teosentris menuntut untuk pandai menjangkarkan kepentingan (interest) kepada nilai (value) dalam politik. ${ }^{42}$ Pancasila mengakui tentang Ketuhanan. ${ }^{43}$

${ }^{41}$ Jimly Asshiddiqie, Gagasan Negara Hukum Indonesia, http : // www. jimly. Com / makalah / namafile / 135 /Konsep_Negara_Hukum_Indonesia pdf, diakses pada hari Senin, 27 Juni 2016 jam 23.00 WIB.

${ }^{42}$ Pimpinan MPR dan Tim Kerja Sosialisasi MPR Periode 2009-2014, Empat Pilar Kehidupan Berbangsa dan Bernegara, (Jakarta: Sekretariat Jenderal MPR RI, 2013), hlm. 46-47. 
Tuhan Yang Maha Esa menetapkan doktrin akan keEsaan dan Kekuasaan-Nya (the unity and souverenity of God). Ajaran ini menjangkau seluruh aspek kehidupan manusia, tidak terkecuali aspek politik ketatanegaraan serta pemerintahan. ${ }^{44} \mathrm{Di}$ antara ayat hukum Tuhan yang berkenaan dengan kepemimpinan adalah Surat the Women verse 58-59: Indeed, Allah commands you to render trusts to whom they are due and when you judge between people to judge with justice. Excellent is that which Allah instructs you. Indeed, Allah is ever hearing and seeing (verse: 58); O you who have believed, obey Allah and obey the messenger and those in authority among you. And if you disagree over anything, refer it to Allah and the Messenger, if you should believe in Allah and the last day. That is the best [way] and best in result (verse: 59).

Ketentuan Tuhan yang menyebutkan: let not believers take disbelievers as allies rather than believers. And whoever [of you] does that has nothing with Allah, except when taking precaution against them in prudence. And Allah warns you of Himself, and to Allah is the [final] destination (al-Kitab - the Family of Imran: 28). Sejalan dengan ketentuan Tuhan sebelumnya, utusan Tuhan (the messenger) yang menyebutkan bahwa: each one of you is a leader and each of you is responsible for what you lead. Pada kesempatan lain disebutkan bahwa the Scientists heirs of the Prophets.

Berdasarkan ketentuan Tuhan dan utusan-Nya dalam hubungandengan penentuan kandidat presiden diketahui bahwa kandidat presiden itu harus taat kepada Tuhan dan
utusan-Nya, amanah, shiddiq, tabligh, dan fathanah. Berdasarkan intensitas hukum mutlak dipahami bahwa hukum Tuhan tidak boleh diabaikan oleh manusia dengan alasan apapun. Larangan terhadap pengabaian itu dikarenakan kegunaan hukum itu adalah untuk kebaikan manusia itu sendiri. Ketika pengabaian hukum Tuhan terjadi maka tidak akan ada wujud keadilan, kepastian, dan kemanfaatan hukum dalam artian yang sesungguhnya. Begitu juga tidak akan muncul kesadaran dan kepatuhan hukum di tengah-tengah masyarakat.

Peringatan Tuhan sangat jelas, diantaranya menyebutkan: Then seest thou such a one as takes as his god his own vain desire? Allahhas, knowing [him as such], left him astray, and sealed his hearing and hisheart [and understanding], and put a cover on his sight. Who, then, will guidehim after Allah [has withdrawn guidance]? Will ye not then receive admonition?(Q.S. Jatsiya (45): 23).O ye people! adore your guardian-lord, who created you and those who camebefore you, that ye may have the chance to learn righteousness(Q.S. Baqara (2): 21). Who has made the earth your couch, and the heavens your canopy; and sentdown rain from the heavens; and brought forth therewith Fruits for yoursustenance; then set not up rivals unto Allah when ye know [the truth]. (Q.S. Baqara (2): 22).

Tantangan untuk lahirnya kesadaran dan kepatuhan kepada hukum Tuhan datang dari manusia yang suka membangkang, manusia yang memperturutkan hawa nafsu, manusia yang bersangkutan membutuhkan hidayah Tuhan dalam kehidupannya.

${ }^{43}$ Budiyono, Hubungan Negara dan Agama Dalam Negara Pancasila, Fiat Justisia Jurnal Ilmu Hukum, Volume 8, Nomor 3, Juli-September 2014, hlm. 410.

${ }^{44}$ Trianto dan Titik Triwulan Tutik, Falsafah Negara dan Pendidikan Kewarganeraan, (Jakarta: Prestasi Pustaka Publisher, 2007), hlm. 229. 


\section{Revitalisasi konstitusional penentuan kandidat presiden melalui pemilihan demokratis}

Revitalisasi konstitusional sebagaimana yang disinggung sebelumnya dalam konteks inimesti diaplikasikan ketika menentukan kandidat presiden melalui pemilihan demokratis. Pemilihan demokratis (democratic elections) tidak sekadar simbol (are not merely symbolic). Elemen-elemen dari pemilihan demokratis adalah kompetitif, periodik, inklusif, definitif. Pemilihan penentuan kandidat presiden dipilih oleh warga yang menikmati kebebasan seluas-luasnya untuk mengkritik pemerintah, menerbitkan kritik mereka dan menyajikan alternatif (they are competitive, periodic, inclusive, definitive elections in which the chief decision-makers in a government are selected by citizens who enjoy broad freedom to criticize government, to publish their criticism, and to present alternatives). ${ }^{45}$

Upaya revitalisasi konstitusional dalam mewujudkan demokrasi dimaksudkan sebagai pemerintahan oleh rakyat melalui pemilihan umum yang bebas dan adil dalam bentukbentuk partisipasi (democracy-rule by the people through free and fair elections and other forms of participation) ${ }^{46}$ Beberapa prinsip demokrasi dan pemilihan demokratis sebagai berikut.

a. Kedaulatan gagasan populer bahwa orang adalah otoritas tertinggi dan sumber kekuasaan pemerintah adalah prinsip dasar demokrasi (popular sovereignty-the idea that the people are the ultimate authority and the source of the authority of government-is a fundamental principle of democracy).

b. Kesetaraan politik semua warga negara merupakan prinsippenting demokrasi (the political equality of all citizens is an essential principle of democracy).

c. Dalam demokrasi, hanya kekuasaan pemerintah didasarkan pada persetujuan yang diperintah (in a democracy, the just powers of government are based upon the consent of the governed).

d. Pemilihan yang bebas dan bentuk lain dari partisipasi masyarakat sangat penting untuk demokrasi (free elections and other forms of civic participation are essential to democracy).

e. Jika orang memerintah, mereka harus memiliki cara praktis menentukan siapa harus melaksanakan kekuasaan politik atas nama mereka (if the people are to rule, they must have practical means of determining who shall exercise political power on their behalf).

f. Jika mereka memerintah, rakyat juga harus memantau dan mempengaruhi perilaku pejabat sementara di kantor (if they are to rule, the people must also monitor and influence officials' behavior while in office).

g. Pemilihan berada di jantung cara praktis rakyat untuk menegaskan kedaulatan mereka (elections are at the heart of the practical means for the People to assert their sovereignty).

${ }^{45}$ photos.state.gov/./Democracy-in-Brief_kor.pdf, diakses pada hari Selasa, 28 Juni 2016 jam 20.00 WIB.

${ }^{46}$ The Concepts and Fundamental Principles of Democracy, http : // www . civiced . org / pdfs / books / Elements Of Democracy / Elements Subsection 3. pdf, diakses pada hari Selasa, 28 Juni 2016 jam 20.00 WIB. 
h. Pemilu harus bebas dan adil (elections must be free and fair). Pemilihan yang bebas (free elections) berarti semua warga negara dewasa dapat memilih dalam pemilihan (all adult citizens can vote in elections). Pemilihan yang adil (fair elections) berarti pemilihan yang pada dasarnya jujur. Pemilih harus tidak dihentikan dari voting dan semua orang harus akurat dihitung (elections that are fundamentally honest. Voters mustnot be stopped from voting and all votes must be accurately counted).

i. Sebagai pengawas pemerintah, rakyat harus memiliki alternatif sumber informasi (as overseers of government, the people must have alternative sources of information).

j.. Tidak ada sumber tunggal, terutama sumber resmi pemerintah, sudah cukup (no single source, especially an official government source, is sufficient). Oleh karena itu, kebebasan pers merupakan aspek penting dari pemerintahan yang demokratis (freedom of the press is therefore an essential aspect of democratic government).

Revitalisasi konstitusional memberikan arahan bahwa pelaksanaan demokrasi dan perwujudan pemilihan demokratis untuk penentuan kandidat presiden melempangkan jalan demi munculnya kandidat presiden yang akan membahagiakan rakyat Indonesia yang dilandasi dengan ketaqwaan kepada Tuhan Yang Maha Esa.

\section{Penentuan Kandidat Presiden Melalui Pemilihan Demokratis di Internal Partai}

Berdasarkan hal sebelumnya tentang pemilihan demokratis, ketika diterapkan di internal partai maka dapat dimaknai sebagai berikut.

1. Pemilihan demokratis adalah kompetitif (democratic elections are competitive). Perbedaan sudut pandang dan perbedaan kandidat harus tetap menjamin adanya hak dan kebebasan berbicara, berkumpul dan gerakan yang diperlukan untuk menyuarakan kritik secara terbuka dan untuk membawa kebijakan alternatif dan calon pemilih. Secara sederhana memungkinkan akses. Aturan dan pelaksanaan pemilihan harus adil dan tanpa kekerasan.

2). Pemilihan demokratis adalah periodik (democratic elections are periodic).

Demokrasi dilakukan tidak memilih diktator atau presiden untuk hidup. Pejabat terpilih bertanggung jawab kepada rakyat dan mereka harus kembali kepemilih pada interval yang ditentukan untuk mencari mandat mereka. Partai hanya media/jalan sehingga jalan itu harusnya lancar untuk mencapai tujuan nasional.

3). Pemilihan demokratis adalah inklusif (democratic elections are inclusive). Warga negara dan pemilih harus cukup besar untuk menyertakan populasi pemilih yang cerdas. Presiden yang dipilih oleh sebagian kecil, kelompok eksklusif tidaklah demokratis. Salah satu drama besar demokrasi sepanjang sejarah telah perjuangan kelompok dikecualikan apakah ras, etnis, atau perempuan untuk memenangkan kewarganegaraan penuh, dan dengan itu hak untuk memilih, memegang jabatan, dan berpartisipasi penuh dalam masyarakat. 
4). Pemilihan demokratis adalah definitif (democratic elections are definitive). Anggota menentukan kepemimpinan pemerintah untuk mengatur jangka waktu. Presiden yang dipilih oleh rakyat memegang tampuk kekuasaan, mereka tidak hanya boneka atau simbolik.

Demokrasi berkembang pada keterbukaan dan akuntabilitas, dengan satu pengecualian yang sangat penting, seperti tindakan voting diri. Untuk meminimalkan kesempatan untuk intimidasi, pemilihdalam demokrasi harus diizinkan untuk memberikan suara mereka diam-diam. Pada saat yang sama, perlindungan pemungutan suara dan menghitung dari total suara harus dilakukan sebagai sesuatu yang transparan, sehingga warga yakin bahwa hasilnya akurat dan bahwa pemerintah memang bersandar pada persetujuan mereka.

Menurut Pasal 10 Ayat (1) UndangUndang Nomor 42 Tahun 2008 berbunyi: "Penentuan calon presiden dan/atau calon wakil presiden dilakukan secara demokratis dan terbuka sesuai dengan mekanisme internal partai politik bersangkutan". Setiap partai politik di Indonesia menentukkan mekanisme pemilihan presiden dan wakil presiden dalam AD/ART.

Pemegang kedaulatan partai politik berada di tangan anggota yang mempunyai hak dalam menentukan kebijakan serta hak memilih dan dipilih. Undang-Undang Partai Politik mewajibkan setiap partai politik memelihara daftar anggotanya, serta salah satu sumber keuangan partai politik adalah iuran anggota.
Secara demokratis diartikan sebagai persaingan terbuka antarcalon dan anggota partai politik yang menentukan hasil persaingan (partisipasi) maka mekanisme penentuan calon presiden dan wakil presiden yang dilakukan oleh partai politik selama ini berlangsung secara tidak demokratis. Penentuan pasangan calon presiden dan wakil presiden oleh partai politik harus memenuhi dua persyaratan demokrasi berupa persaingan terbuka antarcalon dan partisipasi anggota dalam menentukan hasil persaingan.

Bila ditinjau secara normatif berdasarkan ketentuan AD/ART partai politik diketahui bahwa pada umumnya partai politik dikelola secara demokratis, seperti dari AD/ART salah satu partai (Partai Golkar) sebagai berikut:

1. Partai Golongan Karya sepenuhnya mengemban hakikat partai politik sebagai pilar demokrasi dan kekuatan politik rakyat untuk memperjuangkan cita-cita dan aspirasinya secara mandiri, bebas dan demokratis. ${ }^{47}$

2. Rekrutmen jabatan politik untuk calon presiden dan wakil presiden, gubernur dan wakil gubernur, bupati dan wakil bupati, dan walikota dan wakil walikota dilakukan melalui proses penjaringan dan penyaringan dengan memperhatikan: a. mekanisme yang demokratis dan terbuka, b. kapabilitas dan profesional. ${ }^{48}$

Partai Golkar mempersiapkan mekanisme yang demokratis untuk melakukan seleksi internal terhadap calon presiden dan wakil presiden yang akan diajukan oleh partai. ${ }^{49}$

${ }^{47} \mathrm{AD} / \mathrm{ART}$ Partai Golongan Karya.

${ }^{48}$ Pasal 28 AD ART Partai keadilan Sejahtera.

${ }^{49}$ Zae, Perlu Seleksi Internal Partai yang Demokratis Soal Capres, http : // www . hukum online .com/ berita/ baca / hol 7729/perlu-seleksi-internal-partai-yang-demokratis-soal-capres, diakses pada hari Selasa, 27 Juni 2016 jam 21.30 WIB. 
Mekanisme yang digunakan oleh Partai Golkar disebut Konvensi Nasional. Konvensi dilakukan dalam tiga tahap. Tahap pertama, proses penjaringan calon oleh partai. Pada tahap ini dilakukan sosialisasi kepada masyarakat bahwa Partai Golkar membuka pendaftaran bagi siapa saja yang ingin menjadi presiden melalui partai golkar. Siapapun boleh daftar, walaupun ia bukan dari Golkar dan memenuhi syarat dalam Undang-Undang Pemilihan Presiden setelah nanti disahkan. Setelah itu, nama-nama calon yang terkumpul tersebut akan disosialisasikan ke daerah, kepada DPD TK I di provinsi, kepada DPD TK II di kabupaten/kota, selanjutnya kepada tingkat kecamatan dan desa.

Kemudian tahap kedua, dilakukan seleksi calon-calon tersebut melalui rapat pleno yang diperluas. Rapat pleno tersebut akan dilakukan di tingkat DPD I oleh Panitia Konvensi Daerah yang terdiri dari pengurus DPD TK I, DPD TK II, dan organisasi masyarakat (ormas) Partai Golkar. Prosesnya dilakukan secara terbuka, bisa diliput dan langsung diumumkan.

Tahap terakhir adalah konvensi nasional partai yang dilakukan oleh anggota DPP, DPD TK I, DPD TK II, dan ormas partai. Konvensi ini akan menyeleksi dan memilih nama-nama calon yang diajukan oleh rapat pleno yang diperluas tadi. Kemudian, hasilnya diajukan sebagai usulan partai.

Berdasarkan prinsip revitalisasi konstitusional maka intensitasnya mesti mengindahkan peringatan Tuhan. Di antara peringatan Tuhan menyebutkan:"and verily this Brotherhood of yours is a single brotherhood, and $i$ am your lord and cherisher: therefore fear me [and no other]. But people have cut off their affair [of unity], between them, into sects:each party rejoices in that which is with itself. But leave them in their confused ignorance for a time.Do they think that because we have granted them abundance of wealth andsons, we would hasten them on in every good? Nay, they do not understand(Q.S. Mukminun (23); 52-56)".

Proses yang dilaksanakan di internal Partai Golkar disebut sebagai demokrasi internal. Setelah syarat ini tercapai maka partai politik yang telah menang pemilu tersebut akan ikut mendukung proses demokrasi dan tidak akan menjadi ancaman bagi pranata demokrasi. Suatu sistem demokrasi mengharuskan semua partai politik untuk selalu menerapkan demokrasi internal. Demokratisasi internal menjamin adanya dialog terbuka dalam proses pembentukan kehendak politik. Dalam suatu partai politik harus ada sistem pemilu bebas yang memungkinkan pergantian anggota secara adil dan bisa dipertanggungjawabkan kepada publik. Para pemimpin dan fungsionaris partai memiliki kecenderungan untuk menghimpun kekuasaan di dalam parpol mereka dan pada berebut kekuasaan di luar partai. Demokrasi internal yang berjalan dengan baik akan mengimbangi kecenderungan ini dan menjaga struktur organisasi agar tetap terbuka terhadap kontrol demokratis dan partisipasi anggotanya serta memberikan kesempatan bagi masyarakat madani untuk memberikan pengaruhnya. ${ }^{50}$

Sangat penting untuk dijadikan bahan renungan realitas yang disebutkan oleh Teguh Imansyah dalam tulisannya yang berjudul "Regulasi Partai Politik Dalam Mewujudkan Penguatan Peran dan Fungsi Kelembagaan Partai Politik (Regulatory Political Parties to Realize Role and Function of Strengthening Institutional Political Parties)". Realitas yang berkembang saat ini justru menunjukan

${ }^{50}$ Thomas Meyer, Peran Partai... Op. Cit., hlm. 34-35. 
kelembagaan partai-partai yang ada sedang berada pada titik terendah. Keadaan tersebut dapat terlihat dari kasus-kasus pelanggaran hukum yang saat ini marak terjadi diantara para kader partai, khususnya bagi anggota Dewan Perwakilan Rakyat (DPR) ataupun sebagai pejabat negara.

Laporan yang dipublikasikan oleh Indonesia Corruption Watch (ICW) memaparkan bahwa terdapat 52 kader partai politik yang terjerat kasus korupsi pada tahun 2012, dengan rincian 25 orang dari kalangan mantan DPR/ DPRD, 24 orang dari kalangan kepala daerah dan 2 orang pengurus partai serta 1 orang yang menjabat sebagai menteriaktif. ${ }^{51}$ Beberapa partai politik yang terkait kasus korupsi melalui jalur politik, diantaranya Partai Golkar, Partai Demokrat, Partai Demokrasi Indonesia Perjuangan (PDIP), Partai Amanat Nasional (PAN), Partai Kebangkitan Bangsa (PKB), Parta Keadilan Sejahtera (PKS), Partai Gerakan Indonesia Raya (Gerindra), Partai Persatuan Pembangunan (PPP). Modus yang sering dilakukan oleh politisi ini adalah memanfaatkan kewenangan jabatannya, dengan begitu mereka dapat memainkan anggaran. ${ }^{52}$

Hasil kajian dari kemitraan menyebutkan bahwa kasus-kasus korupsi yang melibatkan politisi, baik yang berasal dari lingkungan legislatif maupun eksekutif, sesungguhnya bukan semata-mata karena motif pribadi. Faktor kebutuhan partai politik akan dana besar agar bisa memenangkan pemilu telah mendorong para politisi untuk berlaku koruptif. Secara umum para politisi di DPR mempunyai empat cara dalam mengumpulkan dana, yaitu Pertama, membuat kebijakan yang menguntungkan pihak tertentu. Kedua, menyusun rencana proyek dan anggarannya dalam APBN yang kelak akan dikerjakan oleh pihak tertentu. Ketiga, menjadi calo tender proyek. Keempat, meminta imbalan atas pemilihan jabatan publik atau pimpinan BUMN. ${ }^{53}$

Empat bentuk modus yang dilakukan oleh para politisi DPR untuk meraup dana, membuktikan bahwa telah terjadi kartelisme dalam tubuh legislatif dan partai. Hanta Yuda menyebutkan bahwa meluasnya kasus korupsi dan semakin menurunnya produktifitas kinerja lembaga legislatif, sangat berkaitan dengan manajemen pengorganisasian yangtidak transparan, oligarki, dan transaksional di dalam tubuh partai. The Indonesia Institute menemukan adanya indikasi kegagalan partai politik dalam menjalankan fungsi perekrutan politik secara demokratis, transparan dan berbasis meritokrasi. Pengisian kepengurusan di dalam partai seringkali dilakukan melalui cara-cara yang kental dengan kartelisme.Tidak hanya kartelisme yang telah menggerogoti kelembagaan partai politik di Indonesia, namun virus pragmatisme juga menggerogoti perilaku para elite partai, kader, dan konstituen partai, virus oligarkisme menjangkiti model kepemimpinan dan pengambilan keputusan di dalam partai, dan virus faksionalisme yang melemahkan kelekatan organisasi partai. Dengan kondisi kelembagaan partai yang sedemikian rupa, tidak dapat diharapkan terciptanya ikatan

${ }^{51}$ Teguh Imansyah, Regulasi Partai Politik Dalam Mewujudkan Penguatan Peran dan Fungsi Kelembagaan Partai Politik(Regulatory Political Parties to Realize Role and Function of Strengthening Institutional Political Parties), Jurnal Recht Vinding Media, Pembinaan Hukum Nasional, Volume 1, Nomor 3, Desember 2012, hlm. 376.

${ }^{52} \mathrm{Ibid}, \mathrm{hlm} .377$.

${ }^{53} \mathrm{lbid}$. 
idiologis didalam tubuh partai dan gejala lompat pagar para politisi sering terjadi. ${ }^{54}$

Berbagai bentuk kegagalan dalam kelembagaan partai dapat ditelusuri dari elemen-elemen yang mengalami disfungsi. Misalnya, terjadinya penguatan pragmatisme, dampak dari gagalnya partai politik menjalankan sistem kaderisasi, ideologisasi dan fungsi pendidikan politik bagi kader dan pemilih. Seperti alur kausalitas yang tidak terputus pragmatisme yang hidup di dalam tubuh partai akan memerosotkan militansi kader dan menguatnya pragmatisme pemilih. Dengan itu, partai akan cenderung menggunakan cara instan menarik simpati pemilih menggunakan kekuatan politik uang. ${ }^{55}$

Buruknya kelembagaan partai politik, seperti dipaparkan, tentu berpengaruh pada tingkat kepercayaan masyarakat terhadap partai politik. Hasil survei nasional yang pernah dilakukan Centre for Strategic and International Studies (CSIS) di 33 provinsi Indonesia menyebutkan bahwa masyarakat secara umum kecewa terhadap semua partai politik dan cenderung bingung untuk mendukung partai mana. Menurut hasil survei, sebanyak $48,4 \%$ responden menyatakan bahwa mereka tidak memiliki pilihan dalam pemilu. Survei tersebut juga menunjukkan adanya anggapan responden bahwa saat ini semua partai politik sama saja sehingga tidak ada altenatif pilihan partai yang menjanjikan. Munculnya sikap anti partai seperti ini tidak hanya merugikan partai politik, tetapi juga demokrasi di Indonesia secara keseluruhan. ${ }^{56}$

Segenap partai politik harus senantiasa menyadari tujuan dan fungsinya yang telah ditetapkan dalam aturan hukum. Pasal 10 Undang-Undang Nomor 2 Tahun 2008 tentang Partai Politik menyebutkan bahwa:

(1) Tujuan umum partai politik sebagai berikut.

a. mewujudkan cita-cita nasional bangsa Indonesia sebagaimana dimaksud dalam Pembukaan Undang-Undang Dasar Negara Republik Indonesia Tahun 1945.

b. menjaga dan memelihara keutuhan Negara Kesatuan Republik Indonesia.

c. mengembangkan kehidupan demokrasi berdasarkan Pancasila dengan menjunjung tinggi kedaulatan rakyat dalam Negara Kesatuan Republik Indonesia.

d. mewujudkan kesejahteraan bagi seluruh rakyat Indonesia.

(2) Tujuan khusus partai politik sebagai berikut.

a. meningkatkan partisipasi politik anggota dan masyarakat dalam rangka penyelenggaraan kegiatan politik dan pemerintahan.

b. memperjuangkan cita-cita partai politik dalam kehidupan bermasyarakat, berbangsa, dan bernegara.

c. membangun etika dan budaya politik dalam kehidupan bermasyarakat, berbangsa, dan bernegara.

(3) Tujuan partai politik sebagaimana dimaksud pada Ayat (1) dan Ayat (2) diwujudkan secara konstitusional.

Fungsi partai politik disebutkan dalam Pasal 11, yaitu

(1) Partai Politik berfungsi sebagai sarana sebagai berikut.

\footnotetext{
${ }^{54} / \mathrm{bid}$.

${ }^{55} \mathrm{lbid}$.

${ }^{56} / \mathrm{bid}, \mathrm{hlm} .378$.
} 
a. pendidikan politik bagi anggota dan masyarakat luas agar menjadi warganegara Indonesia yang sadar akan hak dan kewajibannya dalam kehidupan bermasyarakat, berbangsa, dan bernegara.

b. penciptaan iklim yang kondusif bagi persatuan dan kesatuan bangsa Indonesia untuk kesejahteraan masyarakat.

c. penyerap, penghimpun dan penyalur aspirasi politik masyarakat dalam merumuskan dan menetapkan kebijakan negara.

d. partisipasi politik warga negara Indonesia.

e. rekrutmen politik dalam proses pengisian jabatan politik melalui mekanisme demokrasi dengan memperhatikan kesetaraan dan keadilan gender.

(2) Fungsi partai politik sebagaimana dimaksud pada Ayat (1) diwujudkan secara konstitusional.

Ketentuan yang menyebutkan bahwa fungsi partai politik sebagaimana dimaksud pada Ayat (1) diwujudkan secara konstitusional menunjukkan bahwa revitalisasi konstitusional sangat penting.

\section{Kesimpulan}

1. Konsepsi revitalisasi konstitusional sebagai proses, cara, perbuatan menghidupkan atau menggiatkan kembali sesuai dengan konstitusi Indonesia dengan landasan filosofis Pancasila berbasiskan kepada Ketuhanan Yang Maha Esa demi wujudnya kebahagiaan bagi rakyat Indonesia.

2. Revitalisasi konstitusional dalam penentuan kandidat presiden berkaitan dengan syarat kandidat presiden dan pemilihan demokratis. Syarat utama kandidat presiden adalah bertaqwa kepada Tuhan Yang Maha Esa, sedangkan pelaksanaan pemilihan demokratis mesti dengan prinsip amanah dan prosedur yang memberi ruang partisipasi seluruh rakyat dilandasi dengan prinsip Ketuhananan Yang Maha Esa.

3. Penentuan kandidat presiden melalui pemilihan demokratis di internal partai dapat dilaksanakan dengan konvensi sehingga memberi ruang bagi kandidat terbaik yangdipilih oleh para pemilih terbaik untuk menjadi kandidat presiden.

\section{Referensi}

Abdul Latif.Pilpres Dalam Perspektif Koalisi Multiparta. Jurnal Konstitusi. Volume 6. Nomor 3. September 2009.

Abu Tamrin. Urgensi Pemilu Presiden dan Wakil Presiden Secara Langsung di Era Reformasi. Jurnal Cita Hukum. Volume I. Nomor 2. Desember 2013.

Ahmad Farhan Subhi. Pengusulan Pasangan Calon Presiden dan Wakil Presiden Sebagai Peserta Pemilu Menurut Undang-Undang Pilpres. Jurnal Cita Hukum. Fakultas Syariah dan Hukum UIN Syarif Hidayatullah Jakarta. Volume II. Nomor 2. Tahun 2015.

Budiyono. Hubungan Negara dan Agama dalam Negara Pancasila. Fiat Justisia Jurnal IImu Hukum. Volume 8. Nomor 3. JuliSeptember 2014.

Departemen Pendidikan Nasional. 2003. Kamus Besar Bahasa Indonesia. Jakarta: Balai Pustaka.

Farahdiba Rahma Bachtiar. Pemilu Indonesia: Kiblat Negara Demokrasi dari Berbagai 
Refresentasi. Jurnal Profetik. Volume 3. Nomor 1. Tahun 2014.

Hendarmin Ranadireksa. 2009. Visi Bernegara

Arsitektur Konstitusi Demokratik. Bandung: Fokusmedia.

John M. Echols dan Hassan Shadily. 2002.Kamus Indonesia Inggris. Jakarta: PT Gramedia.

Lambang Trijono. Reaktualisasi Politik Demokrasi: Politik Agensi dan Revitalisasi Kelembagaan Demokrasi. Jurnal IImu Sosial dan IImu Politik. Volume 15. Nomor 2. November 2011. Mahkamah Konstitusi RI. 2010.Naskah Komprehensif Perubahan UndangUndang Dasar Negara Republik Indonesia Tahun 1945 Buku IV Kekuasaan Pemerintahan Negara, Jilid I.Jakarta: Sekretariat Jenderal dan Kepaniteraan MK.

Masdar Farid Mas'udi. 2013. Syarah UUD 1945 Perspektif Islam. Jakarta: PT Pustaka Alvabet.

Muh. Ikhsan Baso. Sistem Pemilihan Umum Presiden dan Wakil Presiden Indonesia Dengan Pencalonan Secara Independen (Perseorangan). Jurnal IImu Hukum Legal Opinion. Edisi 5. Volume 1. Tahun 2013.

Ni'matul Huda. 2008.UUD 1945 dan Gagasan Amandemen Ulang. Jakarta: Rajawali Pers.

Pimpinan MPR dan Tim Kerja Sosialisasi MPR Periode 2009-2014. 2013.Empat Pilar Kehidupan Berbangsa dan Bernegara. Jakarta: Sekretariat Jenderal MPR RI.
Ramlan Surbakti dkk. 2015. Naskah Akademik dan Draft Ruu Kitab Hukum Pemilu: Usulan Masyarakat Sipil. Jakarta: Kemitraan bagi Pembaruan Tata Pemerintahan di Indonesia.

Satjipto Rahardjo. 2009.Negara Hukum yang Membahagiakan Rakyatnya. Yogyakarta: Genta Publishing.

Sri Handayani Retna Wardani. Tolok Ukur Demokrasi Pancasila Dalam Membentuk Undang-Undang Pemilu Legislatif. Jurnal Kajian Hukum. Volume 1. Nomor 1. Mei 2016.

Teguh Imansyah. Regulasi Partai Politik Dalam Mewujudkan Penguatan Peran dan Fungsi Kelembagaan Partai Politik (Regulatory Political Parties to Realize Role and Function of Strengthening Institutional Political Parties). Jurnal Recht Vinding Media. Pembinaan Hukum Nasional. Volume 1. Nomor 3. Desember 2012.

Thomas Meyer. 2012. Peran Partai Politik Dalam Sebuah Sistem Demokrasi: Sembilan Tesis. Jakarta: FriedrichEbert-Stiftung (FES) Kantor Perwakilan Indonesia.

Trianto dan Titik Triwulan Tutik. 2007.Falsafah Negara dan Pendidikan Kewarganeraan. Jakarta: Prestasi Pustaka Publisher.

Wimmy Halim. Demokrasi Deliberatif Indonesia: Konsep Partisipasi Masyarakat Dalam Membentuk Demokrasidan Hukum yang Responsif. Jurnal Masyarakat Indonesia. Volume 42. Nomor 1. Juni 2016. 